\title{
Flaws in the European Legal Framework with Respect to Gamete Donor Privacy Protection
}

\author{
Gianluca Montanari Vergallo*
}

Although the new European General Data Protection Regulation (GDPR) does include genetic and identity data among those covered by privacy rights, it does not, specifically deal with the issue of gamete donor privacy.

As shown by Articles 6, 9 and 17 of the Regulation, the right to privacy ought to be weighed and balanced against the rights of other parties involved.

In light of the jurisprudence arising from the European Court of Human Rights (ECtHR), knowledge of the circumstances in which one was born, and thus one's biological origins, constitutes a 'vital interest', which is enshrined in Article 8 of the European Convention of Human Rights ${ }^{1}$ (ECHR). Finding the truth about fundamental aspects such as the identity of one's biological parents plays a role in contributing to an individual's development and to the moulding of his or her personality in a broad sense.

Consequently, it seems difficult to argue that the GDPR causes donor privacy to outweigh donor-conceived children's interest.

The primacy of gamete donors' right to anonymity is also not asserted in Directive 2004/23/EC ${ }^{2}$ which applies to tissues and cells, including reproductive ones, ie eggs and sperm (point [7]).

On the one hand, Article 14 of the Directive mandates that all Member States enact necessary measures to ensure that the identity of receivers shall not be disclosed to the donors' families and vice versa. On the other hand, subsection 3 of the Directive allows states to regulate disclosing conditions differently, particularly in case of gamete donation. This is clarified in point [29], which establishes that Member States may, in exceptional circumstances (namely in cases of gamete donations), authorise the revoking of donor anonymity.

\section{DOI: $10.21552 / \mathrm{edpl} / 2018 / 3 / 5$}

* Gianluca Montanari Vergallo, Sapienza University of Rome. For correspondence: <gianluca.montanarivergallo@uniroma1.it>.

1 Godelli v Italy App no 33783/09 (ECtHR, 25 September 2012), § 46, http://hudoc.echr.coe.int/eng?i=001-114323, accessed 30 July 2018; Odièvre v France App no 42326/98 (ECtHR, 13 February 2003); Mikulid v Croatia App no 53176/99 (ECtHR, 7 February 2012).

2 Directive 2004/23/EC of the European Parliament and of the Council of 31 March 2004 on setting standards of quality and safety for the donation, procurement, testing, processing, preservation, storage and distribution of human tissues and cells [2004] OJ L $102 / 48$. 
This ambiguous scenario in the European legislative framework is due to several factors. First and foremost, family law does not fall within the legislative prerogatives of the European Union. It is therefore up to national lawmakers to establish the rules regarding the identity of biological parents and regulate personal and family relationships between parents and their children. Moreover, Article 6 subsection 2 of the Treaty on European Union reflects the Union's adherence to the Convention for the Protection of Human Rights and Fundamental Freedoms, but rules out that such an adherence may somehow alter the Union's prerogatives as spelled out in the founding treatise. Lastly, subsection 3 of the same legislation clearly asserts that the fundamental rights enshrined in the ECHR and emerging from the common constitutional traditions constitute the European Union's general principles.

By virtue of that classification, since the right to know one's biological origins, upheld by the ECtHR, is not an integral part of common constitutional traditions, it seems unlikely that it gets recognized as a principle of European law. Hence, European legislation does not appear to be fit to uniformly regulate the balance between donors' right to anonymity and donor-conceived children's interest in knowing their biological origins. The only prospect for harmonisation rests with constitutional statutes, such as the Italian one ${ }^{3}$, which bind all national legislation to compliance with ECHR.

It is worth wondering whether pieces of legislation that appear to be antithetical among different countries may be compliant with the stated purpose of building a model European Union grounded in common, shared social values. Such misgivings appear well-founded with respect to the issue at hand, since the right to anonymity and the donor-conceived children's right to know their biological origins has social significance which is not solely linked to ethical implications, as, on the contrary, embryo research is. 